\title{
Photophysical properties, electronic and crystal structure of a luminescent pentanuclear gold(I) complex
}

\author{
Biing-Chiau Tzeng, ${ }^{a}$ Chi-Ming Che ${ }^{*, a}$ and Shie-Ming Peng ${ }^{b}$ \\ a Department of Chemistry, The University of Hong Kong, Pokfulam Road, Hong Kong \\ ${ }^{b}$ Department of Chemistry, National Taiwan University, Taipei, Taiwan
}

A novel pentanuclear gold(I) complex with five gold(I) centres held by weak metal-metal interactions has been prepared and its structure characterized by X-ray analysis; it shows interesting photochemistry and dual emissions in solution upon photoexcitation.

The design of new luminescent inorganic materials with novel electrooptical properties is of considerable interest. Our approach to this area is to take advantage of 'aurophilicity', ${ }^{1}$ ligand-ligand interactions and the photoluminescence of gold(I) building blocks. ${ }^{2}$ In this context, a gold(I) quinolinethiolate should be a good building block since: $(i)$ visible photoluminescence arising from $\mathrm{S} \rightarrow \mathrm{Au}$ charge-transfer excitation is anticipated ${ }^{3}$ and (ii) in addition to the gold(I)-gold(I) bonding interaction, it is possible to have a ligand-ligand interaction between the two quinolinethiolate units, thus providing an additional driving force for the formation of polynuclear gold(I) complexes with high nuclearity. Herein is described the preparation and crystal structure of a luminescent pentanuclear gold(I) complex. This is an unprecedented pentanuclear gold(I) complex, which has both gold(I)-gold(I) and ligand-ligand interactions.

The yellow complex $\left[\mathrm{Au}_{5} \mathrm{~L}_{3}(\mathrm{dppm})_{2}\right][\mathrm{MeO}]\left[\mathrm{ClO}_{4}\right][\mathrm{HL}=$ quinoline-2-thiol, dppm = bis(diphenylphosphino)methane $]$ was prepared by the reaction of $\left[(\mathrm{AuCl})_{2}(\mathrm{dppm})\right]^{4}$ with $\mathrm{NaL}$ in $\mathrm{MeOH}+\dagger^{\dagger}$ Fig. 1 shows a perspective view of the $\left[\mathrm{Au}_{5} \mathrm{~L}_{3}(\mathrm{dppm})_{2}\right]^{2+}$ cation. $\$$ The anions include $\mathrm{ClO}_{4}{ }^{-}$and $\mathrm{MeO}^{-}$, and the latter is most probably due to the excess amount of $\mathrm{NaOMe}$ in the reaction. The structure features one of the

† The reaction of equimolar amounts of $\mathrm{NaL}(183 \mathrm{mg})$ [obtained from $\mathrm{HL}(161 \mathrm{mg})$ and $\mathrm{NaOMe}(60 \mathrm{mg})$ in $\left.\mathrm{MeOH}\left(25 \mathrm{~cm}^{3}\right)\right]$ and $\left[(\mathrm{AuCl})_{2}(\mathrm{dppm})\right]^{4}(850 \mathrm{mg})$ in $\mathrm{CH}_{2} \mathrm{Cl}_{2}-\mathrm{MeOH}\left(1: 1,50 \mathrm{~cm}^{3}\right)$ for $4 \mathrm{~h}$ at room temperature gave a yellow solution. Upon addition of $\mathrm{LiClO}_{4}$, the yellow complex $\left[\mathrm{Au}_{5} \mathrm{~L}_{3}(\mathrm{dppm})_{2}\right][\mathrm{MeO}]\left[\mathrm{ClO}_{4}\right]$ was obtained and could be recrystallized by diffusion of diethyl ether into a $\mathrm{CH}_{2} \mathrm{Cl}_{2}$ $\mathrm{MeOH}$ solution (Found: $\mathrm{C}, 39.55 ; \mathrm{H}, 3.20 ; \mathrm{N}, 1.40$. Calc. for $\mathrm{C}_{80} \mathrm{H}_{75} \mathrm{Au}_{5} \mathrm{ClN}_{3} \mathrm{O}_{8} \mathrm{P}_{4} \mathrm{~S}_{3}: \mathrm{C}, 39.25 ; \mathrm{H}, 3.05 ; \mathrm{N}, 1.70 \%$ ).

+ Crystal data for $\left[\mathrm{Au}_{5} \mathrm{~L}_{3}(\mathrm{dppm})_{2}\right][\mathrm{MeO}]\left[\mathrm{ClO}_{4}\right] \cdot \mathrm{CH}_{2} \mathrm{Cl}_{2} \cdot \mathrm{EtOH}$. $2 \mathrm{H}_{2} \mathrm{O} . \quad \mathrm{C}_{81} \mathrm{H}_{77} \mathrm{Au}_{5} \mathrm{Cl}_{3} \mathrm{~N}_{3} \mathrm{O}_{8} \mathrm{P}_{4} \mathrm{~S}_{3}, \quad M \quad 2531.78$, triclinic, space group $P \overline{1}, a=15.835(4), b=17.115(4), \quad c=17.461(4) \AA, \quad \alpha=$ $85.43(2), \beta=83.70(2), \gamma=67.68(2)^{\circ}, U=4347.8(17) \AA^{3}, D_{\mathrm{c}}=1.921 \mathrm{~g}$ $\mathrm{cm}^{-3}, D_{\mathrm{m}}=1.915 \mathrm{~g} \mathrm{~cm}^{-3}, Z=2, F(000)=2355$, crystal dimensions $0.01 \times 0.10 \times 0.35 \mathrm{~mm}$. Intensity data were collected on an EnrafNonius CAD4 diffractometer with graphite-monochromated Mo-K $\alpha$ radiation $(\lambda=0.7107 \AA), 11187$ unique reflections $\left(2 \theta<45^{\circ}\right)$ were measured and 4228 with $I>2 \sigma(I)$ were used in the refinement. The structure was solved and refined by full-matrix least squares using the NRCVAX program. ${ }^{5}$ Refinement of positional and anisotropic thermal parameters for all non-hydrogen atoms (866 variables) converged to $R=0.067$ and $R^{\prime}=0.064\left[w^{-1}=\sigma^{2}(F)\right]$. The final Fourier-difference map showed residual extrema from 2.24 to -1.50 e $\AA^{-3}$. Atomic coordinates, thermal parameters and bond lengths and angles have been deposited at the Cambridge Crystallographic Data Centre (CCDC). See Instructions for Authors, J. Chem. Soc., Dalton Trans., 1996, Issue 1. Any request to the CCDC for this material should quote the full literature citation and the reference number 186/10. few examples of pentanuclear gold(I) complexes and has the five gold(I) centres held by the bridging dppm and L ligands and perhaps weak metal-metal interactions. The arrangement of the five gold(I) centres is different from that of the $\left[\left\{\mathrm{Au}\left(\mathrm{C}_{6} \mathrm{H}_{2} \mathrm{Me}_{3}-2,4,6\right)\right\}_{5}\right]$ complex reported in the literature ${ }^{6}$ which has a star-shaped structure and with $\mathrm{Au}^{\mathrm{I}} \ldots \mathrm{Au}^{\mathrm{I}}$ ranging from 2.692(4) to 2.710(3) $\AA$. The $\mathrm{Au}^{\mathrm{I}} \ldots \mathrm{Au}^{\mathrm{I}}$ separations in the present complex lie between 2.936(3) and 3.351(3) $\AA$. The Au(1), $\mathrm{Au}(2)$ and $\mathrm{Au}(3)$ atoms are roughly in a linear array with

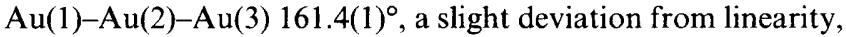
with $\mathrm{Au}(1)$ having a weak bonding interaction with $\mathrm{Au}(5)$ [Au(1)-Au(5) 3.067(3) $\AA]$. Both the Au(2)-Au(5) [3.351(3) $\AA]$ and $\mathrm{Au}(3)-\mathrm{Au}(4)$ [3.333(4) $\AA]$ distances are very long, suggesting very weak metal-metal interaction. It is noted that the closest $\mathrm{L} \cdots \mathrm{L}$ separation is around $3.30 \AA[\mathrm{C}(7) \cdots \mathrm{C}(25)$ $3.31, \mathrm{C}(6) \cdots \mathrm{C}(23) 3.35 \AA$; the average separation between the two least-squares quinoline planes is $3.80 \AA]$ suggesting the existence of a weak $\pi-\pi$ interaction between the quinoline ligands. These ligands bridge in a bidentate manner with $\mathrm{Au}-\mathrm{S}$ (av.) 2.28(2) and Au-N(av.) 2.10(4) $\AA$

The pentanuclear gold(I) complex shows room-temperature photoluminescence upon excitation at $300-400 \mathrm{~nm}$. The UV/ VIS spectrum measured in acetonitrile at room temperature [Fig. 2 (insert)] displays intense absorption ranging from $c a$. 330 to $420 \mathrm{~nm}$ with absorption maxima at $c a .370 \mathrm{~nm}(\varepsilon=$ $\left.21900 \mathrm{dm}^{3} \mathrm{~mol}^{-1} \mathrm{~cm}^{-1}\right)$ and a shoulder at $c a .385 \mathrm{~nm}(\varepsilon=$ $18250 \mathrm{dm}^{3} \mathrm{~mol}^{-1} \mathrm{~cm}^{-1}$ ). Since the free thiol (HL) shows absorptions at similar energies, the $330-420 \mathrm{~nm}$ absorptions seem to be dominated by the intraligand transitions of the thiolate ligands. It is likely that the metal-centred $5 \mathrm{~d} \longrightarrow 6 \mathrm{~s} / 6 \mathrm{p}$ transition arising from the weak $\mathrm{Au}(\mathrm{I}) \cdot \ldots \mathrm{Au}(\mathrm{I})$ interactions, and the $S \rightarrow A u$ charge-transfer transition sit underneath the intraligand transition. Recently, Bruce and co-workers ${ }^{3}$ reported a series of dinuclear gold(I) thiolate complexes with $\mathrm{Au}(\mathrm{I}) \cdots \mathrm{Au}(\mathrm{I})$ interactions, which show absorption bands at 330-360 $\mathrm{nm}$ assignable to $\mathrm{S} \rightarrow \mathrm{Au}$ charge-transfer transitions. The complex $\left[\mathrm{Au}_{5} \mathrm{~L}_{3}(\mathrm{dppm})_{2}\right][\mathrm{MeO}]\left[\mathrm{ClO}_{4}\right]$ shows dual emissions with maxima at ca. $500(\tau \approx 1.9)$ and $605 \mathrm{~nm}(\tau \approx 1.6$ $\mu \mathrm{s})$ in degassed acetonitrile solution. The emission spectrum is shown in Fig. 2. The high-energy emission most likely comes from the intraligand $(\mathrm{L})$ or metal-to-ligand $\left[\mathrm{Au} \longrightarrow \pi^{*}(\mathrm{dppm})\right.$ or $\left.\mathrm{Au} \longrightarrow \pi^{*}(\mathrm{~L})\right]$ excited state. Since the low-energy emission is comparable in energy to those emissions of $\left[\mathrm{Au}_{2}(\mathrm{dppm})_{2}\right]^{2+}$ $(575){ }^{7} \quad\left[\mathrm{Au}_{3}(\mathrm{dmmp})_{2}\right]^{3+} \quad[580, \quad \mathrm{dmmp}=$ bis(dimethyl phosphinomethyl)methylphosphine $],{ }^{8}\left[\mathrm{Au}_{3}(\mathrm{dpmp})_{2}\right]^{3+}[600$, dpmp $=$ bis(diphenylphosphinomethyl)phenylphosphine $]^{9}$ and $[\mathrm{Au}(\mathrm{SPh})(\mathrm{tpa})](596 \mathrm{~nm}, \mathrm{tpa}=1,3,5$-triaza-7-phosphaadamantane), ${ }^{10}$ the emitting state could arise from the metalcentred $5 \mathrm{~d} \longrightarrow 6 \mathrm{~s} / 6 \mathrm{p}$ transition, although the possibility of having the $\mathrm{S} \rightarrow \mathrm{Au}$ and/or the intraligand $\pi \longrightarrow \pi^{*}$ chargetransfer character in the excited state cannot be excluded.

This communication highlights the synthesis of luminescent polynuclear gold(I) complexes from [AuL]. The resulting pentanuclear gold(I) complex would be a good precursory candidate to study the effect of gold(I)-gold(I) and ligand- 


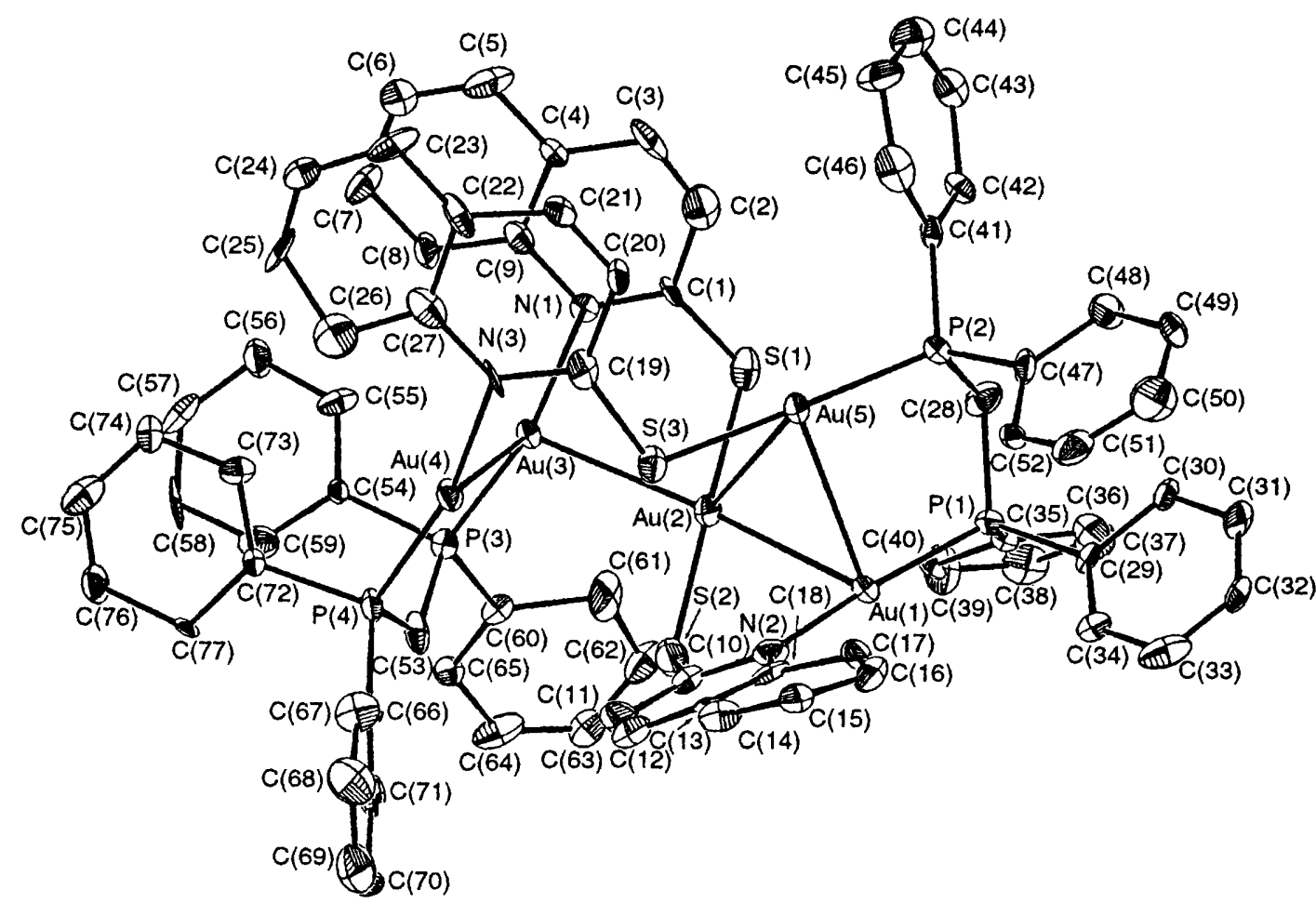

Fig. 1 A perspective view of the $\left[\mathrm{Au}_{5} \mathrm{~L}_{3}(\mathrm{dppm})_{2}\right]^{2+}$ cation. Selected bond lengths $(\AA)$ and angles $\left({ }^{\circ}\right): \mathrm{Au}(1)-\mathrm{Au}(2) 3.038(3), \mathrm{Au}(2)-\mathrm{Au}(3) 2.936(3)$, $\mathrm{Au}(3)-\mathrm{Au}(4)$ 3.333(4), $\mathrm{Au}(1)-\mathrm{Au}(5)$ 3.067(3), $\mathrm{Au}(2)-\mathrm{Au}(5)$ 3.351(3), Au(1)-P(1) 2.25(1), Au(1)-N(2) 2.09(4), Au(2)-S(1) 2.269(16), Au(2)-S(2) 2.242(15), $\mathrm{Au}(3)-\mathrm{P}(3)$ 2.246(14), $\mathrm{Au}(3)-\mathrm{N}(1)$ 2.10(4), $\mathrm{Au}(4)-\mathrm{P}(4)$ 2.260(14), $\mathrm{Au}(4)-\mathrm{N}(3)$ 2.12(4), $\mathrm{Au}(5)-\mathrm{S}(3)$ 2.321(14), $\mathrm{Au}(5)-\mathrm{P}(2)$ 2.266(14); $\mathrm{Au}(1)-\mathrm{Au}(2)-\mathrm{Au}(3)$ 161.4(1), $\mathrm{Au}(1)-\mathrm{Au}(2)-\mathrm{Au}(5)$ 57.13(7), $\mathrm{Au}(2)-\mathrm{Au}(1)-\mathrm{Au}(5)$ 66.57(8), $\mathrm{Au}(2)-\mathrm{Au}(3)-\mathrm{Au}(4)$ 90.26(9), $\mathrm{Au}(3)-\mathrm{Au}(2)-\mathrm{Au}(5)$ 110.7(1), P(1)-Au(1)-N(2) 167.0(12), S(1)-Au(2)-S(2) 171.3(6), P(3)-Au(3)-N(1) 165.9(10), P(4)-Au(4)-N(3) 167.3(10), S(3)-Au(5)-P(2) 178.8(5)



Fig. 2 The emission spectrum of $\left[\mathrm{Au}_{5} \mathrm{~L}_{3}(\mathrm{dppm})_{2}\right][\mathrm{MeO}]\left[\mathrm{ClO}_{4}\right]$ in degassed acetonitrile at room temperature (insert is the absorption spectrum in acetonitrile). Excitation at $325 \mathrm{~nm}$

ligand interactions on the photophysical and photochemical properties of polyaurated gold(I) systems. Preliminary study reveals some interesting photochemistry. Photolysis of a degassed acetonitrile solution of $\left[\mathrm{Au}_{5} \mathrm{~L}_{3}(\mathrm{dppm})_{2}\right][\mathrm{MeO}]$ $\left[\mathrm{ClO}_{4}\right]\left(10^{-4} \mathrm{~mol} \mathrm{dm}{ }^{-3}\right)$ and $\mathrm{MV}^{2+}$ [methyl viologen $\left(1,1^{\prime}\right.$ - dimethyl-4,4'-bipyridinium), $10^{-4} \mathrm{~mol} \mathrm{dm}^{-3}$ ] for $10 \mathrm{~min}$ led to a net reaction of $\mathrm{MV}^{+}$, which was identified by its visibleabsorption spectrum at $500-700 \mathrm{~nm}$.

\section{Acknowledgements}

We acknowledge support from the University of Hong Kong, the Hong Kong Research Grants Council and the Croucher Foundation.

\section{References}

1 H. Schmidbaur, Gold Bull., 1990, 23, 11.

2 S. J. Shieh, X. Hong, S. M. Peng and C. M. Che, J. Chem. Soc., Dalton Trans., 1993, 2929.

3 W. B. Jones, J. Yuan, R. Narayanaswamy, M. A. Young, R. C. Elder, A. E. Bruce and M. R. M. Bruce, Inorg. Chem., 1995, 34, 1996.

$4 \mathrm{H}$. Schmidbaur, A. Wohlleben, F. Wagner, O. Orama and G. Huttner, Chem. Ber., 1977, 110,1748.

5 E. J. Cabe, Y. Le Page, J. P. Charland and P. S. White, J. Appl. Crystallogr., 1989, 22, 384.

6 S. Gambarotta, C. Floriani, A. Chiesi-Villa and C. Guastini, J. Chem. Soc., Chem. Commun., 1983, 1304.

7 C. M. Che, H. L. Kwong, V. W. W. Yam and K. C. Cho, J. Chem. Soc., Chem. Commun., 1989, 885; C. M. Che, H. L. Kwong. C. K. Poon and V. W. W. Yam, J. Chem. Soc., Dalton Trans., $1990,3215$.

8 V. W. W. Yam, T. F. Lai and C. M. Che, J. Chem. Soc., Dalton Trans., 1990, 3747

9 D. Li, C. M. Che, S. M. Peng, S. T. Liu, Z. Y. Zhou and T. C. W. Mak, J. Chem. Soc., Dalton Trans., 1993, 189.

10 J. M. Forward, D. Bohmann, J. P. Fackler, jun., and R. J. Staples, Inorg. Chem., 1995, 34, 6330.

Received 11th December 1995; Communication 5/08030D 